\title{
Alien hand syndrome
}

\author{
Patricio S. Espinosa, MD, MPH; Charles D. Smith, MD; \\ and Joseph R. Berger, MD
}

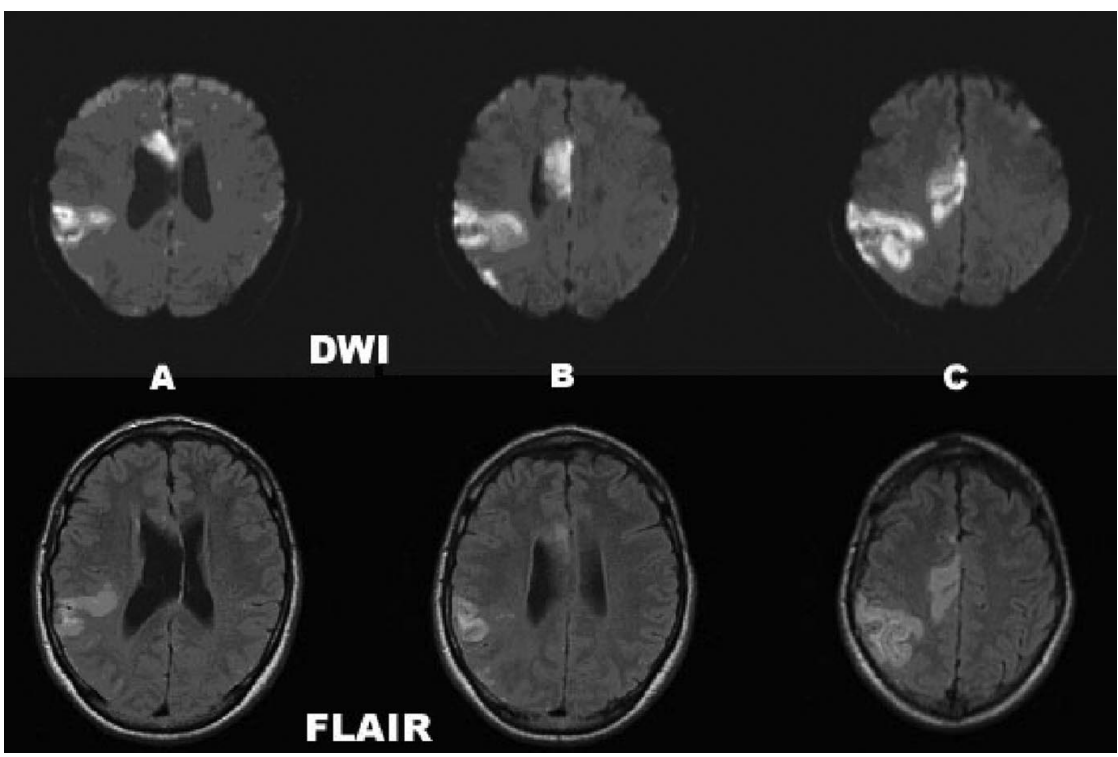

A 47-year-old right-handed man presented with sudden onset of left-sided weakness and incoordination of his left hand. The patient stated that he was not able to operate his left hand appropriately (video E-1). On examination, he had mild weakness in his left arm and leg. When asked to perform tasks with his right hand, his left hand would imitate the other (video E-2). An MRI showed acute ischemic strokes of the right parietal area and anterior corpus callosum (figure).

Alien hand syndrome (AHS) or alien limb sign includes failure to recognize ownership of one's limb when visual cues are removed, a feeling that one body part is foreign, personification of the affected body part, or autonomous activity which is perceived as outside voluntary control. ${ }^{1}$ Although the hand is most frequently affected, any limb or combination of limbs may fulfill the alien limb criteria. ${ }^{1}$

Two types of AHS have been described. Frontal AHS occurs in the dominant hand and is associated with reflexive grasping, groping, and compulsive manipulation of tools. It is a result of damage to the supplementary motor area, anterior cingulate gyrus, and medial prefrontal cortex of the dominant hemisphere and anterior corpus callosum. Callosal AHS is characterized by intermanual conflict and requires only an anterior callosal lesion. Callosal AHS is best explained by hemispheric disconnection manifested during behaviors requiring dominant hemisphere control. ${ }^{2}$

We hypothesize that the alien limb symptoms that our patient demonstrated were secondary to the lesion in the anterior corpus callosum; however, some of his behavioral manifestations may have
Figure. MRI of the brain DWI and FLAIR showing the acute stroke in the right parietal lobe and anterior corpus callosum (see file 1). been exacerbated by the concurrent right parietal stroke. The latter may be associated with hemispatial neglect, typically characterized by directional hypokinesia for actions into and toward contralesional hemispace or failure to respond to stimuli on the left side. ${ }^{3}$ Anosognosia, or unawareness of the neurologic deficit, is frequent after right parietal lesions, and may compound the disability deriving from the neglect itself, ${ }^{3,4}$ although no characteristic features of neglect were observed in our patient.

\section{References}

1. Doody RS, Jankovic J. The alien hand and related signs. J Neurol Neurosurg Psychiatry 1992;55:806-810.

2. Feinberg TE, Schindler RJ, Flanagan NG, Haber LD. Two alien hand syndromes. Neurology 1992;42:19-24.

3. Buxbaum LJ, Ferraro MK, Veramonti T, et al. Hemispatial neglect: subtypes, neuroanatomy, and disability. Neurology 2004;62:749-756.

4. Levine DN, Calvanio R, Rinn WE. The pathogenesis of anosognosia for hemiplegia. Neurology 1991;41:1770-1781. 


\title{
Neurology
}

\author{
Alien hand syndrome \\ Patricio S. Espinosa, Charles D. Smith and Joseph R. Berger \\ Neurology 2006;67;E21 \\ DOI 10.1212/01.wnl.0000249303.88754.48
}

This information is current as of December 26, 2006

\section{Updated Information \& Services}

Supplementary Material

\section{References}

Citations

Subspecialty Collections

Permissions \& Licensing

Reprints including high resolution figures, can be found at: http://n.neurology.org/content/67/12/E21.full

Supplementary material can be found at: http://n.neurology.org/content/suppl/2006/12/21/67.12.E21.DC1 http://n.neurology.org/content/suppl/2007/06/11/67.12.E21.DC2

This article cites 4 articles, 4 of which you can access for free at: http://n.neurology.org/content/67/12/E21.full\#ref-list-1

This article has been cited by 1 HighWire-hosted articles: http://n.neurology.org/content/67/12/E21.full\#\#otherarticles

This article, along with others on similar topics, appears in the following collection(s):

All Neuropsychology/Behavior

http://n.neurology.org/cgi/collection/all_neuropsychology_behavior

MRI

http://n.neurology.org/cgi/collection/mri

Neglect

http://n.neurology.org/cgi/collection/neglect

Information about reproducing this article in parts (figures,tables) or in its entirety can be found online at:

http://www.neurology.org/about/about_the_journal\#permissions

Information about ordering reprints can be found online:

http://n.neurology.org/subscribers/advertise

Neurology ${ }^{\circledR}$ is the official journal of the American Academy of Neurology. Published continuously since 1951, it is now a weekly with 48 issues per year. Copyright . All rights reserved. Print ISSN: 0028-3878. Online ISSN: 1526-632X.

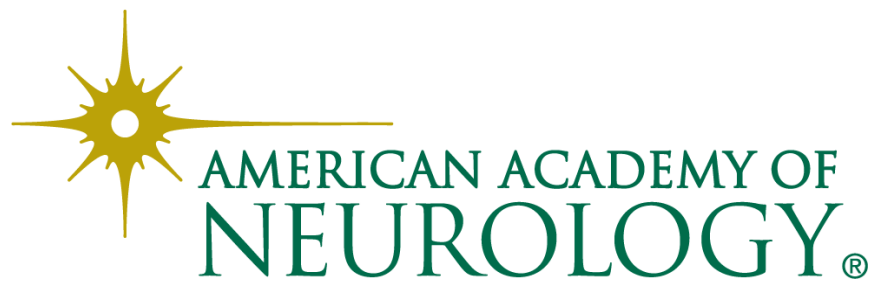

